\title{
Thermal Design of Shell \& Tube Heat Exchanger for Concentrating Solar Power Application
}

\author{
Shridhar S. Thorat ${ }^{+*}$, N. K. Sane ${ }^{\dagger}$ B. S. Gawali ${ }^{\dagger}$, Vinaykumar Kabra ${ }^{\ddagger}$ and Ajit Gavali ${ }^{\ddagger}$ \\ †Department of Mechanical Engineering, Walchand college of Engineering, Sangli, India \\ ‡Power Plants \& Boiler, Walchandnagar Industries Limited, Pune, India
}

Accepted 02 March 2016, Available online 15 March 2016, Special Issue-4 (March 2016)

\begin{abstract}
In the first part of this paper, a simplified approach to Theoretical Thermal Design of Shell \& Tube Heat Exchanger for Concentrating Solar Power Application. The thermal design of STHE involves evaluation of required effective surface area (i.e. number of tubes) and finding out log mean temperature difference [LMTD]. The design was carried out by referring ASME/TEMA standards, available at the company. In the second part of this paper, theoretically (analytical) thermal design of STHE compared with the Software (i.e. HTFS) basis design. Theoretical thermal design validate on the basis of HTFS.
\end{abstract}

Keywords: Heat Exchanger; LMTD, TEMA, HTFS.

\section{Introduction}

Solar thermal power plants produce electricity in much the same way as conventional power stations. The difference is that they obtain their energy input by concentrating solar radiation and converting it to high temperature steam or gas to drive a turbine or engine. Four main elements are required: a concentrator, a receiver, some form of heat transport media or storage, heat exchanger and power conversion. Many different types of systems are possible, including combinations with other renewable and non-renewable technologies.

Heat Exchangers are devices used to enhance or facilitate the flow of heat. Every living thing is equipped in some way or another with heat exchangers. They are widely used in space heating, refrigeration, air conditioning, power plants, chemical plants, petrochemical plants, petroleum refineries, natural gas processing, and sewage treatment. The design of STHE including thermodynamic and fluid dynamic design, cost estimation and optimiza- tion, represents a complex process containing an integrated whole of design rules and empirical knowledge of various fields.

Shell and tube heat exchangers are designed using commercially available software such as those developed by co-operative research organizations such as Heat Transfer and Fluid Flow Service (HTFS) and Heat Transfer Research Inc. (HTRI) and by computer service companies such as B-JAC International. These programs offer design and cost analysis for all primary heat exchanger types and incorporate multiple design

*Corresponding author: Shridhar S. Thorat codes and standards from the American Society of Mechanical Engineers (ASME),Tubular Exchangers Manufacturers Association (TEMA) and the International Standards Organisation (ISO).

\section{Problem Definition}

The most common problems in heat exchanger design are rating and sizing. The rating problem is evaluating the thermo-hydraulic performance of a fully specified exchanger. The sizing problem, however, is concerned with the determination of the dimensions of the heat exchanger.

Table I gives process design data and Table II gives geometric design data required of shell and tube heat exchanger. With considration of above process and geometric prameters, the heat exchanger is designed which gives required tube side fluid outlet temperature.

Table 1 Process Design Data

\begin{tabular}{|c|c|c|c|}
\hline Parameter & Unit & Tube Side & $\begin{array}{c}\text { Shell } \\
\text { Side }\end{array}$ \\
\hline Medium & & Steam & $\begin{array}{c}\text { Dowthe- } \\
\text { rm A }\end{array}$ \\
\hline Mass Flow & $\mathrm{kg} / \mathrm{s}$ & 36.07 & 313.8 \\
\hline Temperature inlet & ${ }^{\circ} \mathrm{C}$ & 315.1 & 393.3 \\
\hline Temperature outlet & ${ }^{\circ} \mathrm{C}$ & 386.1 & 378.7 \\
\hline Oprating pressure & $\mathrm{bar}$ & 17.2 & 105.7 \\
\hline Velocity & $\mathrm{m} / \mathrm{s}$ & 4.506 & 1.1 \\
\hline Fouling resistance & $\begin{array}{c}\mathrm{m}^{2} \cdot \mathrm{K} \\
/ \mathrm{W}\end{array}$ & 0.000088 & 0.000176 \\
\hline $\begin{array}{c}\text { Allowable pressure } \\
\text { drop }\end{array}$ & $\mathrm{bar}$ & 1 & 1 \\
\hline
\end{tabular}


Table 2 Geometric Design Data

\begin{tabular}{|c|c|c|c|}
\hline Parameter & Unit & Tube Side & Shell Side \\
\hline $\begin{array}{c}\text { Inside } \\
\text { diameter }\left(\mathrm{d}_{\mathrm{i}}\right)\end{array}$ & $\mathrm{mm}$ & 19.5 & 2000 \\
\hline $\begin{array}{c}\text { Outside } \\
\left.\text { diameter( } \mathrm{d}_{\mathrm{o}}\right)\end{array}$ & $\mathrm{mm}$ & 25.4 & 2010 \\
\hline $\begin{array}{c}\text { Length of } \\
\text { tube(L) }\end{array}$ & $\mathrm{mm}$ & 7300 & \\
\hline $\begin{array}{c}\text { Number of } \\
\left.\text { passes( } \mathrm{N}_{\mathrm{p}}\right)\end{array}$ & & 2 & \\
\hline Baffle cut & & $20 \%$ & \\
\hline Tube layout & & Squre $\left(90^{\circ}\right)$ & \\
\hline Tube Pitch & $\mathrm{mm}$ & 50 & \\
\hline
\end{tabular}

\section{Theoretical Thermal Design Method}

The thermal design of heat exchangers is directed to calculate an adequate surface area to handle the thermal duty for the given specifications whereas the hydraulic analysis determines the pressure drop of the fluids flowing in the system, and consequently the pumping power or fan work input necessary to maintain the flow.

Petukhov-Popov and Bell-Delaware methods will be presented by performing Thermal Analysis and Hydraulic Analysis separately for the tube-side and for the shell-side.

\subsection{Petukhov-Popov Method}

Tube-Side Nusselt Number

Nusselt number is a function of Reynolds number (Re) and Prandtl number (Pr). However, there are equations developed according to the type of flow. For turbulent flow, the following equation developed by Petukhov-Popov (1963) can be used.

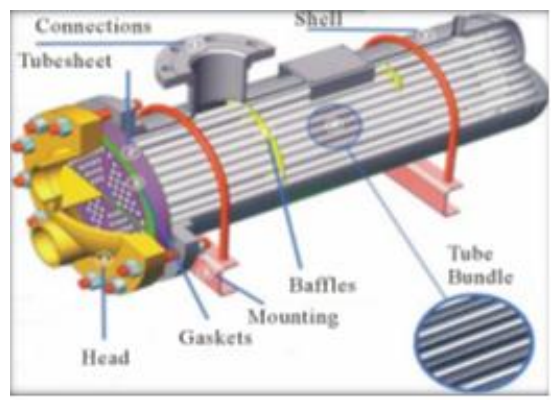

Fig.1 Shell and tube heat exchanger BEU

$$
\mathrm{Nu}_{\mathrm{t}}=\frac{(\mathrm{f} / 2) \mathrm{Re}_{\mathrm{t}} \mathrm{Pr}_{\mathrm{t}}}{\mathrm{C}+12.7\left(\frac{\mathrm{f}}{2}\right)^{\frac{1}{2}}\left(\mathrm{Pr}_{\mathrm{t}}{ }^{\frac{2}{3}}-1\right)}
$$

Where $\mathrm{C}$ and $\mathrm{f}$ is the friction factor turbulent flow in smooth duct

Petukhov-Popov Correlation predicts the results in the range

$4000 \leq \mathrm{Re}_{\mathrm{t}} \leq 5 \times 10^{6}, 0.5 \leq \operatorname{Pr}_{\mathrm{t}} \leq$

$10^{6}$ with accuracy $\pm 5 \%$.
Tube-Side Heat Transfer Co-efficient

$$
\mathrm{h}_{\mathrm{t}}=\mathrm{Nu}_{\mathrm{t}} \frac{\mathrm{k}_{\mathrm{t}}}{\mathrm{d}_{\mathrm{i}}}
$$

Hydraulic Analysis for Tube-Side

The pressure drop encountered by the fluid making passes through the heat exchanger is a multiple of the kinetic energy of the flow. Therefore, the tube-side pressure drop is calculated by

$$
\Delta \mathrm{p}_{\mathrm{t}}=\left(4 \mathrm{f} \frac{\mathrm{LN}_{\mathrm{p}}}{\mathrm{d}_{\mathrm{i}}}+4 \mathrm{~N}_{\mathrm{p}}\right) \frac{\rho_{\mathrm{t}} \mathrm{u}_{\mathrm{t}}^{2}}{2}
$$

\subsection{Bell-Delaware Method}

Bell Delaware method is a rating analysis. The BellDelaware method offers the most widely accepted method.

\section{Simplified Mechanisms of Shell-Side Flow}

As can be seen from Fig., five different streams are identified on the shell-side. Stream B is the main cross flow stream flowing through one window across the cross flow section and out through the opposite window.

However, there are four other streams because of the mechanical clearances required in a shell-and-tube heat exchanger. One of them is the A stream that leaks through the clearance between the tubes and the baffle. There is also the $\mathrm{C}$ stream which is the bundle bypass stream. The $\mathrm{E}$ stream flows through the clearance between the baffles and the inside diameter of the shell. Finally, the F stream flows through any channels within the tube bundle caused by the provision of pass dividers in the exchanger header.
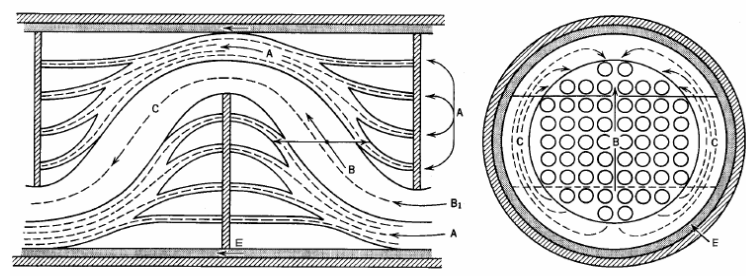

Fig.2 Diagram indicating leaking paths for shell side flow

In Bell Delaware method correction factors were introduced for the following elements:

(a) Leakage through the gaps between the tubes and the baffles and the baffles and the shell, respectively.

(b) Effect of the baffle configuration.

(c) Bypassing of the flow around the gap between the tube bundle and the shell.

(d) Effect of adverse temperature gradient on heat transfer in laminar flow. 


\section{Shell-Side Heat Transfer Coefficient}

In the Bell-Delaware method, the shell side heat transfer coefficient $h_{s}$ is determined using Eq. 0 by correcting the ideal heat transfer coefficient $h_{\text {id }}$ for various leakage and bypass flow streams in a segmental baffled shell-and-tube exchanger.

$\mathrm{h}_{\mathrm{id}}=0.27 \frac{\mathrm{k}_{\mathrm{s}}}{\mathrm{d}_{\mathrm{o}}} \operatorname{Re}^{0.63} \operatorname{Pr}^{0.36}\left(\frac{\operatorname{Pr}_{\infty}}{\operatorname{Pr}_{\mathrm{W}}}\right)^{0.25}$

Shell side mass velocity as,

$\mathrm{G}_{\mathrm{s}}=\frac{\dot{\mathrm{m}}_{\mathrm{s}}}{\mathrm{A}_{\mathrm{o}, \mathrm{cr}}}$

Shell side Reynolds number as,

$\operatorname{Re}_{\mathrm{s}}=\frac{\mathrm{G}_{\mathrm{s}} \mathrm{d}_{\mathrm{o}}}{\mu_{\mathrm{s}}}$

It is then corrected by five correction factors as follows:

$\mathrm{h}_{\mathrm{s}}=\mathrm{h}_{\mathrm{id}} \mathrm{J}_{\mathrm{c}} \mathrm{J}_{\mathrm{l}} \mathrm{J}_{\mathrm{b}} \mathrm{J}_{\mathrm{s}} \mathrm{J}_{\mathrm{r}}$

Hydraulic Analysis for Shell-Side

Similar to shell-side heat transfer, the shell-side pressure drop is also affected by various leakage and bypass streams in a segmentally baffled exchanger.

$$
\begin{aligned}
& \Delta \mathrm{p}_{\mathrm{s}}=\Delta \mathrm{p}_{\mathrm{cr}}+\Delta \mathrm{p}_{\mathrm{w}}+\Delta \mathrm{p}_{\mathrm{i}-\mathrm{o}} \\
& \begin{aligned}
\Delta \mathrm{p}_{\mathrm{s}}=\left[\left(\mathrm{N}_{\mathrm{b}}-1\right)\right. & \left.\Delta \mathrm{p}_{\mathrm{b}, \mathrm{id}} \zeta_{\mathrm{b}}+\mathrm{N}_{\mathrm{b}} \Delta \mathrm{p}_{\mathrm{w}, \mathrm{id}}\right] \zeta_{\mathrm{l}} \\
& +2 \Delta \mathrm{p}_{\mathrm{b}, \mathrm{id}}\left(1+\frac{\mathrm{N}_{\mathrm{r}, \mathrm{cw}}}{\mathrm{N}_{\mathrm{r}, \mathrm{cc}}}\right) \zeta_{\mathrm{b}} \zeta_{\mathrm{s}}
\end{aligned}
\end{aligned}
$$

Overall heat transfer coefficients

$$
\frac{1}{U_{o}}=\frac{1}{h_{s}}+R_{o f}+\frac{d_{o}}{k} \ln \frac{d_{o}}{d_{i}}+\frac{d_{o}}{d_{i}} R_{f i}+\frac{d_{o}}{d_{i}} \frac{1}{h_{t}}
$$

\section{Heat transfer area}

$\mathrm{A}_{\mathrm{o}}=\frac{\mathrm{Q}}{\mathrm{U}_{\mathrm{o}} \mathrm{LMTD}}$

The inputs are given to HTFS software and results are obtained. For the same process conditions shown in Table I and Table II heat exchanger is designed and developed by using software. From the measured Parameters heat duty is calculated. Result of therotical and software designs are compared.

\section{Results and Discussion}

The heat exchanger is for the $30 \mathrm{MW}$ solar thermal power plant. The validation of therotical thermal design is based on HTFS Software results.

The analytical and software results for heat transferred (Fig. 3), Log mean temperature difference (Fig. 4), Pressure drop (Fig. 5), Heat transfer area (Fig. 6) are compared and relative difference is checked.
The graph in fig. 3, fig. 4, fig. 5, fig. 6 shows that we have get heat transfer $10 \%$ more than that analytical method. Also pressure drop \& Heat transfer area get minumum.

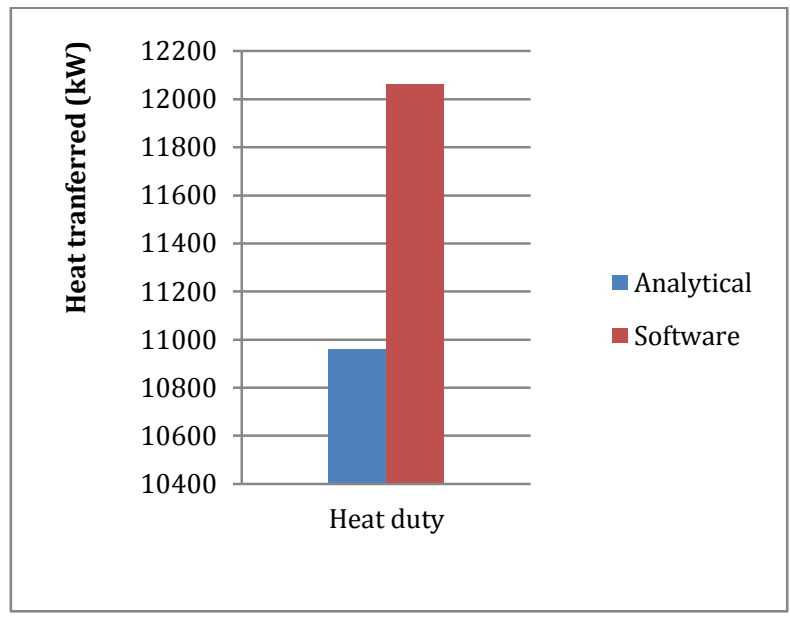

Fig.3 Heat transferred for heat exchanger

In same dimension means no. of tube, tube daimeter, shell daimeter, tube length we get optimised area \& pressure drop, increase in heat duty.

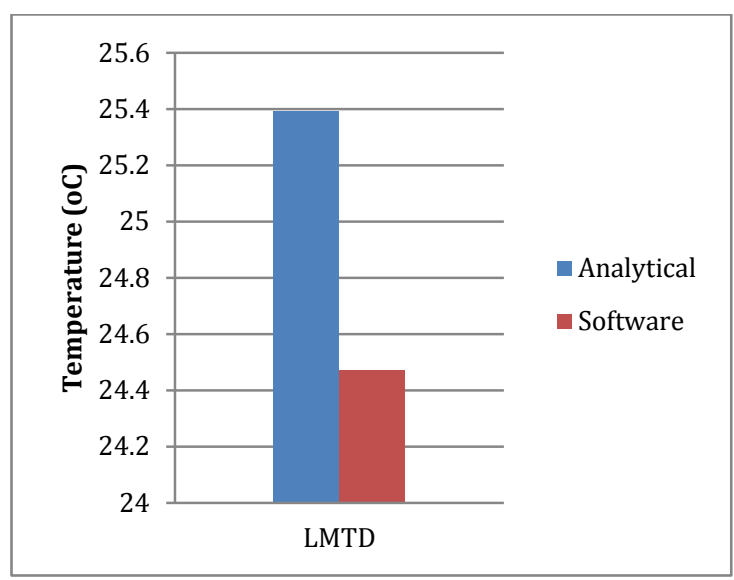

Fig.4 LMTD for heat exchanger

Mass velocity strongly influences the heat-transfer coefficient. For turbulent flow, the tubeside heattransfer coefficient varies to the 0.8 power of tubeside mass velocity, whereas tubeside pressure drop varies to the square of mass velocity. Thus, with increasing mass velocity, pressure drop increases more rapidly than does the heat-transfer coefficient. Consequently, there will be an optimum mass velocity above which it will be wasteful to increase mass velocity further.

Furthermore, very high velocities lead to erosion. However, the pressure drop limitation usually becomes controlling long before erosive velocities are attained. The minimum recommended liquid velocity inside tubes is $1.0 \mathrm{~m} / \mathrm{s}$, while the maximum is $2.5-5.0 \mathrm{~m} / \mathrm{s}$. 


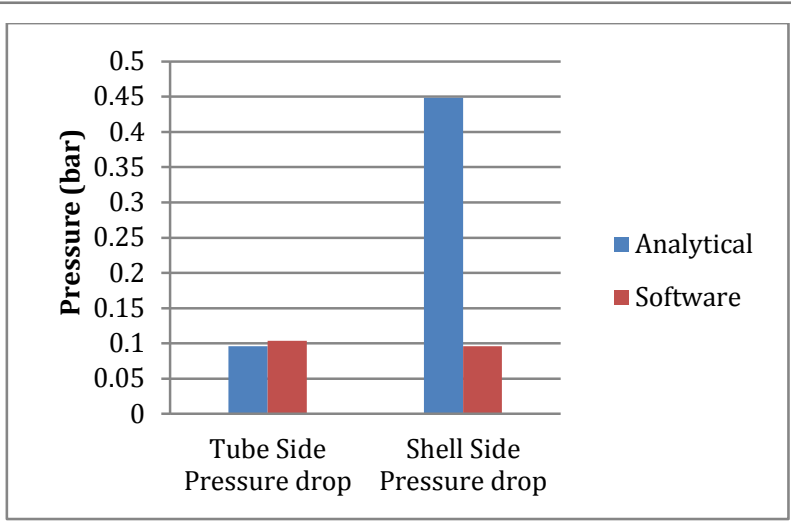

Fig.5 Pressure drop for heat exchanger

It is strongly recommended that only baffle cuts between $20 \%$ and $35 \%$ be employed. Reducing baffle cut below $20 \%$ to increase the

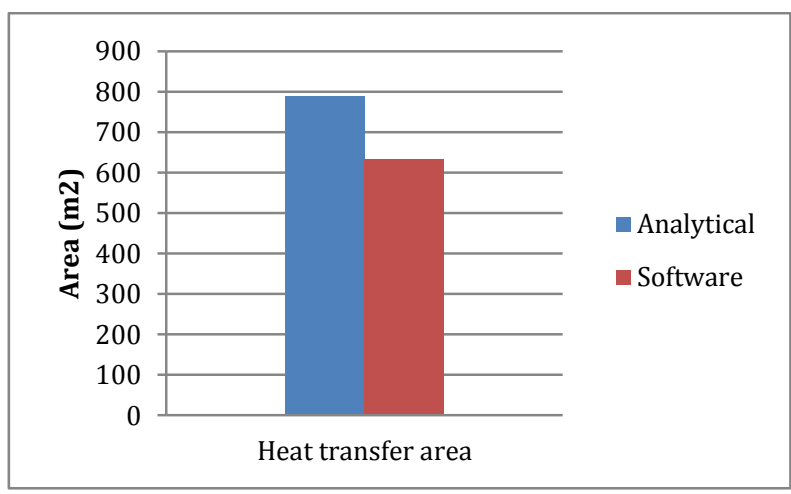

Fig.6 Heat transfer area for heat exchanger

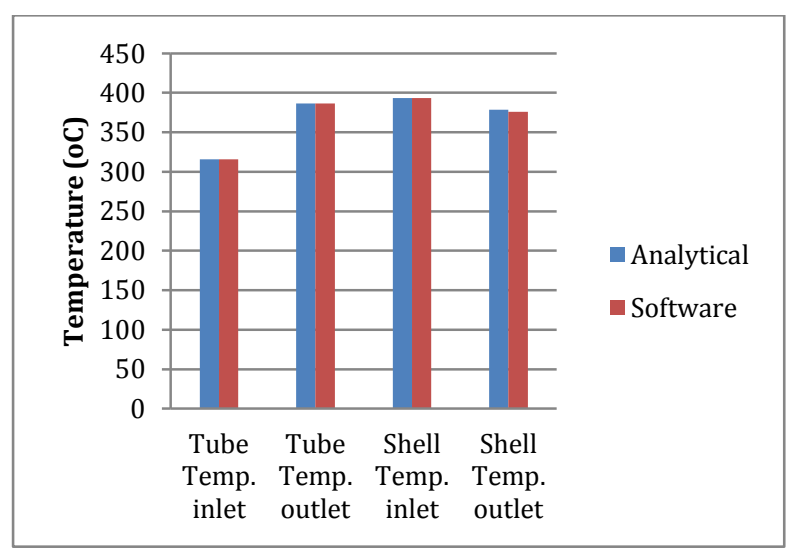

Fig.7 Temperature of heat exchanger

Shell side heat-transfer coefficient or increasing the baffle cut beyond $35 \%$ to decrease the shellside pressure drop usually lead to poor designs.

The graph in fig. 7, fig. 8 show that outlet temperature of heat exchanger achived by simulation mode is exact to the analytical method \& tube side heat transfer coefficient is more, shell side heat transfer coefficient is less \& overall heat transfer coefficient is also less than that of analytical method.

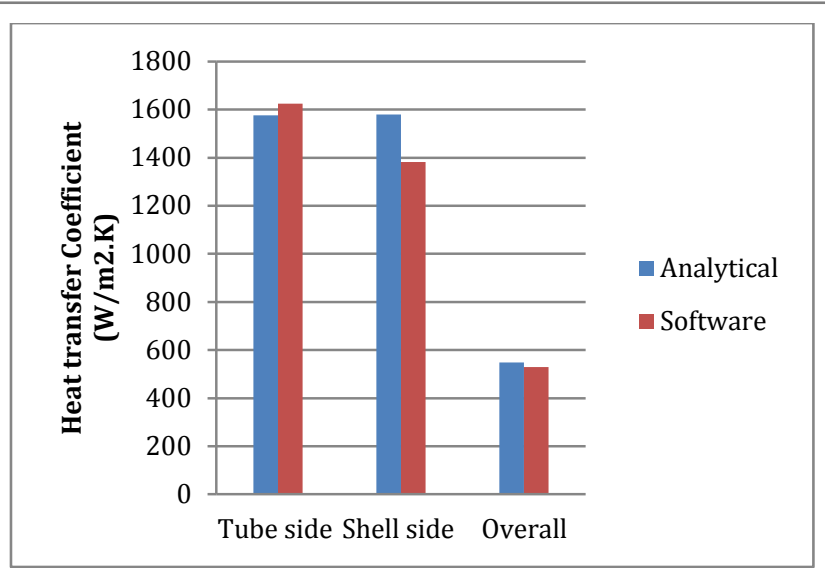

Fig.8 Heat transfer coefficient for heat exchanger

Heat transfer coefficients are depends on Reynolds number, Prandtl Number, velocity, diameter. Heat transfer coefficient varies as per these parameter varies.

\section{Conclusions}

Rating \& Sizing of heat exchanger is done analytically and by using the Aspen HTFS software to perform required heat duty. Also it is validated using Aspen HTFS Software.

The following conclusion are drawn,

1) Inlet \& outlet temp. of heat exchanger are achived by software is exact to calculated by anaylatical method

2) Overall heat transfer coefficient \& Tube side heat tansfer coefficient is more than calculated by anaylatical method.

3) Pressure drop, LMTD \& Area of heat exchanger are smaller than calculated.

4) Fouling factor has large influence in the calculation of surface area.So steps like periodic cleaning to maintain lower fouling condition may be less expensive than purchasing additional surface area.

5) The relative difference between analytical results and software results is very less $(<10 \%)$.

6) In simulation mode we have get exact results as in rating mode.

Thus, proven thermal design methodology is set to Thermal Design of Shell \& Tube Heat Exchanger for Concentrating Solar Power Application by studying various parameters affecting on it.

\section{References}

Shravan H. Gawande, Sunil D. Wankhede, Rahul N. Yerrawar, Vaishali J. Sonawane, Umesh B. Ubarhande, (2012), Design and Development of Shell \& Tube Heat Exchanger for 
Beverage, Modern Mechanical Engineering, 2012, 2, 121125.

Srbislav B. Genic, Branislav M. Jac'imovic, Marko S. Jaric, Nikola J. Budimir, Mirko M. Dobrnjac, (2012), Research on the shell-side thermal performances of heat exchangers. International Journal of Heat and Mass Transfer 55 (2012) 4295-4300, Elsevier Ltd.

P M V Subbarao, Professor,Design Fundamentals of Shell and Tube Heat Exchangers, Mechanical Engineering Department I I T Delh.

Standard of the tubular exchanger manufacturing association, (2007), Ninth edition.
Rajiv Mukherjee, February (1998), Engineers India Ltd. , Chemical Engineering progress, American Institute of Chemical Engineers.

R. K. Shah \& D. P. Sekulic,( 2003), fundamentals of Heat exchanger Design, John Wiley \& Sons, Inc.

J. Kenneth Salisbury, (1950) Steam Turbines and their Cycles, Printed in the united state of America.

K.J. Bell, A.C. Mueller, Wolverine Tube Heat Exchanger Data Book, Wolverine Division of UOP Inc., 1st edition, pp. 273$321,1980$.

D.Q. Kern, (2004), Process Heat Transfer, Tata McGraw Hill. 